\section{Responsibility as an Ethical Value}

\section{Mihai AMANOLOAE 1}

${ }^{1}$ Faculty of Law and Administrative Sciences, Ştefan cel Mare University of Suceava, Romania, amanoloaemihai@gmail.com
Abstract: The individual thinking of each of us causes many of us to give up the utopian dreams of the human mastery over living conditions and the exercise of a new responsibility, in accordance with our new powers. Our ethical responsibility and our fateful ontological choice is to do what is necessary to ensure the continued, worldly integrity of mankind and it's continuity in an indefinite future, to ensure a good continuation of life between communities or even in the relations between the states of the world. We point out as a first example the ecological crisis and the moral crisis of transforming ecological behavior into a habit when humanity needs resources to survive. However, it is necessary to give recognition to researchers who claim that traditional systems of ethics do not have the resources to cope with our unprecedented technological powers, and the effort of all to fill the philosophical void but also the real, tangible and practically proven part of ethics with an "ethics of responsibility", it is something other than a simple daily habit.

Keywords: responsibility; ethical values; self-responsibility; social responsibility.

How to cite: Amanoloae, M. (2020). Responsibility as an Ethical Value. Moldavian Journal for Education and Social Psychology, 4(1), 14-19. https://doi.org/10.18662/mjesp/4.1/12 


\section{Introducere}

Crearea unei noi etici a responsabilității este sarcina de luptă a noastră, a tuturor indivizilor, invocând resursele complete ale abilităţilor şi mijloacelor atât filozofice, cât şi materiale pe care le avem, pentru a da o notă adaptativă comportamentelor noastre şi a ne concentra cu toții asupra responsabilităţii. Suntem duşi astfel spre direcția opusă a iresponsabilităţii şi este important să apreciem cu atenție natura şi forța acestui argument.

Prin responsabilitate, ca şi valoare importantă a eticii, oamenii au găsit un răspuns, de multe ori filosofic, la manifestările lor concretizate în acțiuni, la ceea ce trebuie să facă şi cum să se comporte în situaţii multiple, pentru a lua hotărâri în timpul vieții lor de zi cu zi.

Responsabilitatea trebuie înţeleasă ca un element de intermediere şi comunicare interpersonală, în detrimentul succesului şi crearea unei bune reputaţii. Cel care acţionează responsabil şi corect este cel care contribuie la crearea transparenței. Astfel, el devine promotorul acțiunii îndreptate spre o moralitate impecabilă, prin acest mod manifestându-şi disponibilitatea spre succes, bună reputație şi o moralitate desăvârşită.

\section{Responsabilitatea ca latură a moralității personalităţii}

$\mathrm{Cu}$ toții putem înțelege că responsabilitatea este reprezentată de capacitatea individuală a fiecărui om de a înțelege consecințele propriilor acțiuni, dar mai ales de a fi responsabil pentru faptele pe care le întreprinde. Individul alege să facă sau să nu facă ceva deoarece după momentul acțiunii sale urmează o sancțiune sau o consecință (Breaz, 2018), responsabilitatea primând în toate domeniile de activitate şi în toate relaţiile interumane, chiar şi atunci când individul se raportează doar la sinele său.

Având mai multe conotații semantice, conceptul de responsabilitate prezintă o largă acceptare morală şi juridică, fiind strâns legat de categoriile de „bine” şi „,justiție”, de „datorie” şi „drept” (Pivniceru \& Luca, 2008). „Ea apare ca latură a moralităţii personalității, în raport cu reguli şi principii morale - ghid pentru actele comise în chip voluntar. Responsabilitatea clamează reflexia anterioară asupra consecinţelor alegerilor, deciziilor şi acțiunilor noastre, ca fiind proporțională cu previziunea. Atitudine de conştiință şi practică, prin care ceea ce trebuie este asumat şi respectat, împlinit în baza convingerii, responsabilitatea este măsură a libertăţii. De altminteri, cele două categorii de valori nu pot funcționa decât în interacțiune” (Sandu, 2015).

Sub aceste aspecte putem lega responsabilitatea de „moralitate sau natura etică a unei acțiuni - caracterul ei bun sau rău - (...) care trebuie să fie 
judecate în funcție de măsura în care ea include şi integrează scopurile şi asigură dezvoltarea potențială a acestor scopuri pentru toți oamenii implicați în acţiunea respectivă sau care ar putea fi afectați de ea" (Sandu, 2015). Distingem că cei care nu respectă acest joc al responsabilităţii vor suporta consecințele de rigoare (Cantrill, 2002).

\section{Responsabilitatea ca valoare socială}

Ca individ al societăţii actuale, fiecare doreşte să se manifeste liber în beneficiul său, dar ca persoană morală, fiecare doreşte să contribuie la schimbarea pozitivă a lumii. Această motivație, în mod ideal, nu trebuie să intre în conflict cu responsabilităţile de la locul de muncă sau cu aspecte de ordin financiar. Intersecția dintre profitul personal şi imperativul moral poate ajuta la stabilirea direcției fiecăruia, ca una responsabilă din punct de vedere etic.

Tendința către responsabilitate etică poate fi întâlnită în multe companii mari din toate domeniile vieții sociale, care au îmbrăţişat ideea că îşi pot desfăşura activitatea într-o manieră responsabilă din punct de vedere etic. Intreprinderile mici nu au îmbrățişat în aceeaşi manieră această idee, poate datorită faptului că în societățile comerciale mici primează dorinţa de acumulare de capital, în condițiile în care responsabilitatea etică înseamnă o menținere a indivizilor într-un mediu etic, cu cheltuirea de resurse pentru creşterea nivelului etic al celor care se află sub pragul promovat de corporație, în timp ce aceasta îşi setează un obiectiv mai înalt, de a contribui pozitiv la societate. Parțial, liderii companiilor cu orientare pozitivă pregătesc manageri seniori sau alţi angajați, care în timp ajung să stabilească obiective noi pentru alte activităţi etice, de la filantropia faţă de comunitate şi până la programe de excelență în protecția mediului. Companiile sunt, de asemenea, motivate de aşteptările externe: clienții, acționarii, investitorii şi publicul larg pot face ca aceste companii să fie preocupate nu doar de profiturile imediate, ci şi de imaginea lor publică.

De exemplu, când doi bărbați afro-americani au fost arestați în 2018 la un centru Starbucks din Philadelphia pentru că au ocupat spațiul într-un centru de consum Starbucks, dar nu au cumpărat nimic, povestea a stârnit o reacție extraordinară în social media. Starbucks a acționat în consecință prin închiderea tuturor magazinelor sale pentru o perioadă, iar compania şi-a instruit apoi miile de angajați în ceea ce priveşte sensibilitatea rasială pentru clienți (Orso, 2019). Iată un exemplu de asumare a responsabilității, pentru a evita consecințele negative viitoare şi de aceea numeroase organizaţii au creat 
linii directoare pentru comportamentul etic al salariaților, indiferent de dimensiunea companiei.

Responsabilitatea, în general, reprezintă o preocupare atât în relațiile publice, cât şi la nivelul fiecărui individ în parte, precum şi în cel al instituției sau colectivitâții din care acesta face parte. Relaţiile publice reprezintă conştiința legăturilor interumane sau al colectivităților şi un mod de a experimenta această conştiinţă este responsabilitatea.

Pentru a determina responsabilitatea socială, evidențiem că o parte cheie a activităţii responsabile etice este găsirea unor modalităţi de a minimiza orice impact social negativ pe întregul lanț al acțiunilor noastre zilnice. Spre exemplu, responsabilitatea comunității la locul de muncă se identifică prin operațiunile proprii ale salariaţilor, dar şi prin cele ale lanţului de aprovizionare, care ar trebui să respecte standardele de la locul de muncă şi din comunitatea în care organizația activează. Responsabilitatea companiilor ar trebui să fie îndreptată spre comunităţile locale în ceea ce priveşte respectarea culturii şi obiceiurilor, sponsorizarea activităților comunitare sau contribuția la cauzele importante pentru comunitate.

\section{Importanța responsabilității între valorile etice}

Astfel cum afirmă profesorul Antonio Sandu (2015), importanţa valorii responsabilităţii, pe teritoriul eticii şi deontologiei rezultă şi din abordarea, tot mai deasă şi clară, a sintagmei coduri de responsabilitate profesională. Astfel denumite, ele arată clar faptul că profesiile pot fi ghidate în practica lor de norme specifice, care exprimă valorile de bază ale fiecărei profesii şi care pun preț pe acele îndrumări de bună practică ce ar putea ghida atitudinea profesioniştilor în situaţii de incidente sau potențiale incidente etice.

„Termenul de responsabilitate vizează capacitatea individului de a răspunde pentru faptele sale. În acest sens este invocată răspunderea juridică, adică capacitatea de exercițiu a persoanei şi implicit posibilitatea de a fi sancționată pentru abaterile de la normativitate. Răspunderea juridică este văzută ca o formă de răspundere socială a individului, înțeleasă ca obligație a acestuia de a suporta consecințele propriei fapte. Încălcarea unei norme de drept atrage sancțiunea în baza unei proceduri formale de stabilire a vinei şi vinovăţiei”" (Sandu, 2015).

Mai departe, ştim şi trebuie să luăm în serios faptul că toată viaţa organică a evoluat din şi rămâne în natură. Toți suntem sau ar trebui să fim, post-darwinieni, oameni de ştiinţă şi filozofi deopotrivă. Însă lucrurile fundamental sau substanțial diferite nu se încadrează cu uşurinţă într-o singură schemă etică. Îndemnul către un „monism” filosofic care respectă diversitatea 
şi complexitatea deplină a realului a fost întotdeauna o opțiune mai atractivă rațională decât uniformitatea etică.

În concluzie, aceste trăsături umane caracteristice rezultă în mod natural şi sunt implicate permanent în dinamica tărâmului natural etic al omului. Intenția de a adopta un comportament etic este o caracteristică fundamentală a ființei naturale, iar responsabilitatea pentru propriile acte este o orientare activă către viața în comunitate, mai degrabă decât o orientare pasivă sau lipsită de interes ce ar pune pe prim plan propria individualitate. Auto-responsabilitatea ajută la determinarea satisfacției şi a succesului în domeniile sociale ale vieții noastre. Dar auto-responsabilitatea nu trebuie confundată cu noțiunea populară New Age că noi suntem cauza a tot ceea ce se întâmplă în viața noastră. Această credinţă falsă poate crea serioase piedici pentru o stimă de sine la un nivel confortabil psihologic pentru individ, determinându-ne să ne reproşăm acele evenimente care sunt în afara controlului nostru.

Responsabilitatea apare şi se manifestă în toate domeniile vieții sociale, inclusiv în spațiul educativ, „unde valoarea responsabilității morale stă în atenția formatorilor, cu atât mai mult cu cât ei sunt responsabili pentru însăşi responsabilitatea celor pe care-i educă. Cadrele didactice prezintă un model al responsabilității morale” (Sandu \& Popoveniuc, 2018).

Există o inteligență socială a responsabilității, dra pentru a fi inteligenți cu privire la responsabilitatea pe care o avem în viața noastră socială, trebuie să ne cunoaştem limitele. Auto-responsabilitatea asumată corect nu trebuie confundată cu asumarea responsabilității pentru ceilalți. Asumarea unor sarcini necorespunzătoare este un act de iresponsabilitate față de sine. Iar soluționarea problemelor create de lipsa de responsabilitate a altor indivizi de către alți indivizi contribuie doar la o lipsă de responsabilitate a celor dintâi. Principiul auto-responsabilității implică inclusiv ideea morală conform căreia asumarea responsabilităţii pentru propria noastră existență implică respect pentru responsabilitatea celorlalți.

\section{Concluzii}

Responsabilitatea, ca valoare corespondentă eticii este importantă prin aceea că este unul dintre lianturile care fac posibile ducerea la îndeplinire a misiunii unui grup social. Prezentă în conştiința fiecărui individ sau a fiecărei colectivități, responsabilitatea face posibilă corelarea armonioasă a tuturor domeniilor vieții sociale dintr-o colectivitate. Dar pentru că, în sens kantian, nu avem dreptul să îi tratăm pe ceilalți ca mijloace pentru scopurile noastre, obiectivele care necesită cooperarea şi participarea altora nu pot fi atinse în 
absența responsabilității individuale, stimulată de interesele şi nevoile individuale. Acesta este, de altfel, unul dintre sensurile auto-responsabilităţii. Majoritatea dintre noi suntem mai responsabili în unele domenii ale vieții noastre şi mai puțin responsabili în alte domenii. Deci ar fi simplist să afirmăm că un individ este în mod absolut responsabil sau sau complet iresponsabil. Deşi autoresponsabilitatea totală este dificil de conceput, conştientizarea momentelor de iresponsabilitate este de natură să prevină comportamentele iresponsabile ulterioare.

\section{References}

Breaz, A. M. (2018). Social assistance of women in prison. Postmodern Openings, 9(2), 1-14. https://doi.org/10.18662/po/14

Cantrill, H. (2002). The psychology of social movements. Transaction Publishers.

Orso, A. (2019, April 12). One year later: A timeline of controversy and progress since the Starbucks arrests seen 'round the world. https://www.inquirer. $\mathrm{com} /$ news/starbucks-incident-philadelphia-racial-bias-one-yearanniversary-stutter-dilworth-park-homeless-tables-20190412.html

Pivniceru, M. M., \& Luca, C. (2008). Deontologia profesiei de magistrat. Repere contemporane [Deontology of the magistrate profession. Contemporary landmarks]. Hamangiu.

Sandu, A. (2015). Etică profesională şi transparență în administrația publică [Professional ethics and transparency in public administration]. Didactică şi Pedagogică.

Sandu, A., \& Popoveniuc, B. (Coords.). Etică si integritate în educatie si cercetare [Ethics and integrity in education and research]. Tritonic. 